\title{
Synergetic action of doping and coating on electrochemical performance of lithium manganese spinel as an electrode material for lithium-ion batteries
}

\author{
HALIL ŞAHAN ${ }^{1, *}$, MEHMET NURULLAH ATEŞ ${ }^{2}$, FATMA KILIÇ DOKAN ${ }^{1}$, AHMET ÜLGEN ${ }^{1}$ \\ and ŞABAN PATAT ${ }^{1}$ \\ ${ }^{1}$ Department of Chemistry, Faculty of Science, Erciyes University, 38039 Kayseri, Turkey \\ ${ }^{2}$ Northeastern University Center for Renewable Energy Technology, Department of Chemistry and Chemical Biology, \\ 317 Egan Center, 360 Huntington Avenue, Boston, MA 02115, USA
}

MS received 3 April 2014; revised 7 June 2014

\begin{abstract}
Spinel $\mathrm{LiMn}_{2} \mathrm{O}_{4}$ and multidoped spinel $\mathrm{LiMn}_{1.9} \mathrm{Co}_{0.025} \mathrm{Cr}_{0.025} \mathrm{Ni}_{0.025} \mathrm{Fe}_{0.025} \mathrm{O}_{4}$ were synthesized by the glycine-nitrate method and coated with lithium borosilicate (LBS) in order to enhance the electrochemical performance at room temperature. The structure and electrochemical performance of all samples were characterized by inductively coupled plasma-mass spectrometer (ICP-MS), X-ray diffraction (XRD), differential thermal analysis/thermogravimetry (DTA/TG), scanning electron microscopy (SEM), energy dispersive X-ray analysis (EDX), atomic force microscopy (AFM) and galvanostatic charge-discharge measurements. The XRD analysis shows that the samples exhibit a pure spinel phase. The SEM results indicated that LBS particles had encapsulated the surface of the undoped and multidoped $\mathrm{LiMn}_{2} \mathrm{O}_{4}$ without causing any structural change. The charge-discharge tests showed that $\mathrm{LiMn}_{1.9} \mathrm{Co}_{0.025} \mathrm{Cr}_{0.025} \mathrm{Ni}_{0.025} \mathrm{Fe}_{0.025} \mathrm{O}_{4}$ displays better cycling performance than the pristine $\mathrm{LiMn}_{2} \mathrm{O}_{4}$ at room temperature. However, in the same conditions, LBS-coated $\mathrm{LiMn}_{1.9} \mathrm{Co}_{0.025} \mathrm{Cr}_{0.025} \mathrm{Ni}_{0.025} \mathrm{Fe}_{0.025} \mathrm{O}_{4}$ and $\mathrm{LiMn}_{2} \mathrm{O}_{4}$ have better cycling performance than uncoated samples. The results suggest that multidoped and LBS-coated $\mathrm{LiMn}_{2} \mathrm{O}_{4}$ could develop into a promising cathode material for lithium ion batteries.
\end{abstract}

Keywords. Lithium ion battery; $\mathrm{LiMn}_{2} \mathrm{O}_{4}$; cation doping; surface modifications; electrochemical cycling performance.

\section{Introduction}

Lithium ion batteries which have high energy and power density, are important for consumer electronic devices, portable power tools and vehicle electrification. ${ }^{1-4} \mathrm{Li}_{x} \mathrm{CoO}_{2}$ is a commonly used cathode material in commercial lithium ion batteries and has a charge capacity of $140 \mathrm{mAh} \mathrm{g}^{-1}$ with a practical value of $x$ from 0.5 to 1 . However, the high cost, toxicity and limited abundance of cobalt have been recognized to be disadvantageous. As a result, alternative cathode materials have attracted much interest. One of the most promising candidates is spinel $\mathrm{LiMn}_{2} \mathrm{O}_{4}$, which has a charge storage capacity of $148 \mathrm{mAh} \mathrm{g}^{-1}{ }^{5-9}$ Spinel $\mathrm{LiMn}_{2} \mathrm{O}_{4}$ has the advantages of low-cost, environmental friendliness and high abundance.

However, early work soon identified that stoichiometric $\mathrm{LiMn}_{2} \mathrm{O}_{4}$ shows considerable capacity fading on cycling, associated with structural degradation and poor rate performance. ${ }^{10-19}$

Although the reason for the poor cycling performance is not fully understood, several possible mechanisms have been

*Author for correspondence (halil@erciyes.edu.tr) suggested including Mn dissolution, Jahn-Teller distortion and changes in crystallinity. ${ }^{20-26}$

Several methods for the improvement of cycle life have been suggested. Among these, the substitution of small amount of a ion doping at the Mn sites is the most commonly used. ${ }^{27-30}$ In this case, the basic idea of doping is to stabilize the spinel structure against lattice breakdown or Jahn-Teller distortion during cycling. In particular, the problem of capacity fading in $\mathrm{LiMn}_{2} \mathrm{O}_{4}$ electrodes, which is believed to be at least partly due to the formation of domains of the tetragonally distorted $\mathrm{Mn}^{3+}$ rich phase at high levels of reduction, has been successfully solved by substitution to decrease the $\mathrm{Mn}^{3+} / \mathrm{Mn}^{4+}$ ratio. ${ }^{31}$ Although ion substitution can improve the stability of the spinel structure, and suppress the Jahn-Teller distortion, studies indicate that the dissolution of Mn occurs mainly at the interface between spinel $\mathrm{LiMn}_{2} \mathrm{O}_{4}$ and electrolyte. ${ }^{32,33}$ Therefore, surface modification with various metal oxides ${ }^{34-38}$ such as $\mathrm{Al}_{2} \mathrm{O}_{3}, \mathrm{Co}_{3} \mathrm{O}_{4}$ or $\mathrm{ZnO}$, is considered as one effective method to solve the problem, because these oxides can suppress Mn dissolution by scavenging HF which may originate from the electrolyte.

In a previous study ${ }^{39}$ we successfully coated lithium borosilicate (LBS) on the surface of $\mathrm{LiMn}_{2} \mathrm{O}_{4}$ and obtained 
satisfactory improvement in capacity retention. In the present study, to improve the capacity fade of the cathode, we used two different modification methods. Firstly, to decrease Jahn-Teller distortion in the compound we tried to substitute part of the manganese site with four typical elements, designated as $\mathrm{LiMn}_{1.9} \mathrm{Co}_{0.025} \mathrm{Cr}_{0.025} \mathrm{Ni}_{0.025} \mathrm{Fe}_{0.025} \mathrm{O}_{4}$, by the glycine nitrate combustion method. Secondly, to avoid $\mathrm{Mn}$ dissolution in the cathode, LBS was coated on the surface of $\mathrm{LiMn}_{1.9} \mathrm{Co}_{0.025} \mathrm{Cr}_{0.025} \mathrm{Ni}_{0.025} \mathrm{Fe}_{0.025} \mathrm{O}_{4}$ particles via the simple solution method. In addition, the correlation of the $\mathrm{LiMn}_{1.9} \mathrm{Co}_{0.025} \mathrm{Cr}_{0.025} \mathrm{Ni}_{0.025} \mathrm{Fe}_{0.025} \mathrm{O}_{4}$ coating layer on the electrochemical performance and structural stability of the $\mathrm{LiMn}_{2} \mathrm{O}_{4}$ cathode material is elucidated and discussed.

\section{Experimental}

All the samples, $\mathrm{LiMn}_{2} \mathrm{O}_{4}, \mathrm{LiMn}_{1.9} \mathrm{Co}_{0.025} \mathrm{Cr}_{0.025} \mathrm{Ni}_{0.025} \mathrm{Fe}_{0.025} \mathrm{O}_{4}$, were synthesized by the glycine-nitrate combustion process. ${ }^{40}$ Stoichiometric amounts of $\mathrm{LiNO}_{3}$ (Riedel-de Haen) and $\mathrm{Mn}\left(\mathrm{CH}_{3} \mathrm{COO}\right)_{2} \cdot 4 \mathrm{H}_{2} \mathrm{O}$ (Sigma), $\mathrm{Co}\left(\mathrm{NO}_{3}\right)_{2} \cdot 4 \mathrm{H}_{2} \mathrm{O}$ (Surechem), $\mathrm{Cr}\left(\mathrm{NO}_{3}\right)_{3} \cdot 4 \mathrm{H}_{2} \mathrm{O}$ (Merck), $\mathrm{Ni}\left(\mathrm{NO}_{3}\right)_{2} \cdot 4 \mathrm{H}_{2} \mathrm{O}$ (Merck) and $\mathrm{Fe}\left(\mathrm{NO}_{3}\right)_{3} \cdot 9 \mathrm{H}_{2} \mathrm{O}$ (Merck) were dissolved in distilled water. Glycine (Merck) was added to the solution either as a solid or as a water solution. Its role was to serve both as a fuel for combustion and as a complexant to prevent inhomogeneous precipitation of individual components prior to combustion. Finally, nitric acid with the same mole of acetate anions was added to the solution. The molar ratio of glycine to nitrate was 1:4. The solution was heated continuously without any previous thermal dehydration. Later the solution became a transparent viscous gel which auto-ignited automatically, giving a voluminous, black, sponge-like ash as the product of combustion. The resulting ash was heated at $800^{\circ} \mathrm{C}$ for $12 \mathrm{~h}$.

In order to coat $\mathrm{LiMn}_{2} \mathrm{O}_{4}$ with LBS, xerogels of lithium borosilicate (LBS) were prepared by the sol-gel process using precursors of analar grade tetraethylorthosilicate $\left(\mathrm{Si}\left(\mathrm{C}_{2} \mathrm{H}_{5} \mathrm{O}\right)_{4}\right.$, TEOS) (Merck), boric acid (Panreac) and lithium nitrate (Riedel-de Haen). The precursors were mixed according to their calculated molecular weight percentage under $0.1 \mathrm{~N}$ nitric acid concentration as a catalyst, using the following chemical composition:

$$
20 \% \mathrm{Li}_{2} \mathrm{O}-80 \%\left[0.2 \mathrm{~B}_{2} \mathrm{O}_{3}+0.8 \mathrm{SiO}_{2}\right](\mathrm{LBS}) \text {. }
$$

The above composition and synthesis of LBS samples was proposed by Muralidharan and Venkateswarlu ${ }^{41}$ in earlier studies. In order to obtain the LBS compound, different solutions, labeled from $\mathrm{A}$ to $\mathrm{C}$, were prepared separately by mixing the appropriate amount of precursors. Calculated amounts of ethanol, water and TEOS were mixed in a $250 \mathrm{ml}$ conical flask with a magnetic pellet. The mixture was found to be turbid initially but on stirring a clear solution was obtained. The water:TEOS ratio was maintained at 16:1 to form solution A. Solution B, containing boric acid in ethanol, was added to solution A with continual stirring and $x=$ $0.1 \mathrm{~N}$ nitric acid was also added as an acid catalyst to the above mixture $(\mathrm{A}+\mathrm{B})$. The mixture of solutions $\mathrm{A}$ and $\mathrm{B}$ was stirred for half an hour and later solution $\mathrm{C}$, lithium nitrate in water, was added and stirred continuously at room temperature (RT) for about an hour. The temperature of the mixed solution was raised to $65^{\circ} \mathrm{C}$ and maintained for about $3 \mathrm{~h}$ with continual stirring. The sol was cast into plastic beakers covered with aluminum foil and maintained at $65^{\circ} \mathrm{C}$ in the oven. Aging of the gel was maintained at the same temperature $\left(65^{\circ} \mathrm{C}\right)$ and resulted in transparent/opaque dried gels.

The mixture of the LBS precursor and $\mathrm{LiMn}_{2} \mathrm{O}_{4}$ powders was thoroughly mixed in a agate mortar and pestle, and the mixed powders were then calcined at $425^{\circ} \mathrm{C}$ for $5 \mathrm{~h}$. The weight ratio of the precursor of LBS glass to the $\mathrm{LiMn}_{2} \mathrm{O}_{4}$ powders for this method was $2 \mathrm{wt} \%$.

The cation composition of the base and surface-treated $\mathrm{LiMn}_{2} \mathrm{O}_{4}$ powders was determined by inductively coupled plasma mass spectrometer (ICP-MS, Agilent 7500a) after dissolving the powders in a solution of $0.1 \mathrm{M} 10 \mathrm{ml}$ sulphuric acid of $0.1 \mathrm{M}$ oxalic acid.

The phase identification and evaluation of the lattice parameters of the base and surface-treated $\mathrm{LiMn}_{2} \mathrm{O}_{4}$ powders were carried out by powder X-ray diffraction (XRD) using $\mathrm{CuK}_{\alpha}$ radiation (Bruker AXS D8). The diffractometer was equipped with a diffracted beam graphite monochromator. The diffraction data were collected at $40 \mathrm{kV}$ and $40 \mathrm{~mA}$ over a $2 \theta$ range from $10^{\circ}$ to $90^{\circ}$ with a step size of $0.02^{\circ}$ and a count time of $10 \mathrm{~s}$ per step. The DiffracPlus and WinMetric programs were used to obtain the lattice parameters of the powders. The particle morphology of the powders was examined by means of scanning electron microscopy (SEM) (LEO 440), operated at $20 \mathrm{kV}$.

Tapping-mode atomic force microscopy (TP-AFM) was conducted with a multi-mode coupled with a nanoscope controller, Veeco, which gave the surface information of the prepared materials.

$\mathrm{LiMn}_{2} \mathrm{O}_{4}$ particle samples were prepared by isolated particles on a silicon wafer via the following steps. First, $\mathrm{LiMn}_{2} \mathrm{O}_{4}$ powder was dispersed in absolute ethyl alcohol suspension with a ratio of $1 \mathrm{wt} \%$ by using an ultrasonic wave for $15 \mathrm{~min}$, then the $\mathrm{LiMn}_{2} \mathrm{O}_{4}$ particles were placed onto a silicon wafer from a drop of suspension and then dried at room temperature.

The thermogravimetry (TG) and differential thermal analysis (DTA) measurements were conducted by a Perkin-Elmer (Diamond) high temperature thermal analyzer with 5-20 mg samples and a heating rate of $10^{\circ} \mathrm{C} \mathrm{min}^{-1}$ from 50 to $700^{\circ} \mathrm{C}$ in air.

The electrochemical studies were carried out in twoelectrode Teflon cells. The cells were fabricated by using the bare and surface-treated $\mathrm{LiMn}_{2} \mathrm{O}_{4}$ as a cathode and lithium foil as an anode. A glass fiber separator soaked in electrolyte separated the two electrodes in the Teflon cells. The electrolyte consisted of an $1 \mathrm{M}$ solution of $\mathrm{LiPF}_{6}$ dissolved in ethylene carbonate (Aldrich)/diethyl carbonate (Merck) 
(EC/DEC, 1:1 ratio by volume). For the preparation of the cathode composite, a slurry mixed with $86 \mathrm{wt} \%$ of cathode active material, $9 \mathrm{wt} \%$ of acetylene black conductor (Alfa Aesar) and $5 \mathrm{wt} \%$ of polyvinylidene fluoride (PVDF, Fluka) binder in 1-methyl-2-pyrrolidone (NMP, Merck) was pasted on the aluminum foil current collector which had a diameter of $13 \mathrm{~mm}$, followed by vacuum drying at $120^{\circ} \mathrm{C}$ overnight in a vacuum oven and uniaxial pressing between two flat plates at 2 tons for $5 \mathrm{~min}$. The electrode loading consisted of about $4 \mathrm{mg}$ of cathode active material. Diethyl carbonate, ethylene carbonate and acetylene black were used after being purified according to the methods given in the literature. ${ }^{42}$ Diethyl carbonate: $100 \mathrm{ml}$ DEC was washed with an aqueous $10 \% \mathrm{Na}_{2} \mathrm{CO}_{3}(20 \mathrm{ml})$ solution, saturated $\mathrm{CaCl}_{2}(20 \mathrm{ml})$, then water $(30 \mathrm{ml})$. After drying by standing over solid $\mathrm{CaCl}_{2}$ for $1 \mathrm{~h}$ (note that prolonged contact should be avoided because slow combination with $\mathrm{CaCl}_{2}$ occurs), it was fractionally distilled. Ethylene carbonate: this was dried over $\mathrm{P}_{2} \mathrm{O}_{5}$ then fractionally distilled at $10 \mathrm{mmHg}$ pressure and crystallized from dry ethyl ether, respectively. Acetylene black: this was leached for $24 \mathrm{~h}$ with $1: 1 \mathrm{HCl}$ to remove oil contamination, then washed repeatedly with distilled water. It was then dried in air, and eluted for 1 day each with benzene and acetone. It was again dried in air at room temperature, then heated in a vacuum for $24 \mathrm{~h}$ at $600^{\circ} \mathrm{C}$ to remove adsorbed gases.

Table 1. Elemental analysis results of bare $\mathrm{LiMn}_{2} \mathrm{O}_{4}$ and cationdoped $\mathrm{LiMn}_{2} \mathrm{O}_{4}$ samples.

\begin{tabular}{lc}
\hline $\begin{array}{l}\text { Theoretical cation } \\
\text { composition }\end{array}$ & $\begin{array}{c}\text { Experimental cation } \\
\text { composition }\end{array}$ \\
\hline $\mathrm{LiMn}_{2} \mathrm{O}_{4}$ & $\mathrm{Li}_{0.95} \mathrm{Mn}_{1.89} \mathrm{O}_{4}$ \\
$\mathrm{LiMn}_{1.90} \mathrm{Co}_{0.025} \mathrm{Cr}_{0.025^{-}}$ & $\mathrm{Li}_{0.99} \mathrm{Mn}_{1.90} \mathrm{Co}_{0.023} \mathrm{Cr}_{0.026^{-}}$ \\
$\mathrm{Ni}_{0.026} \mathrm{Fe}_{0.024} \mathrm{O}_{4}$ \\
\hline
\end{tabular}

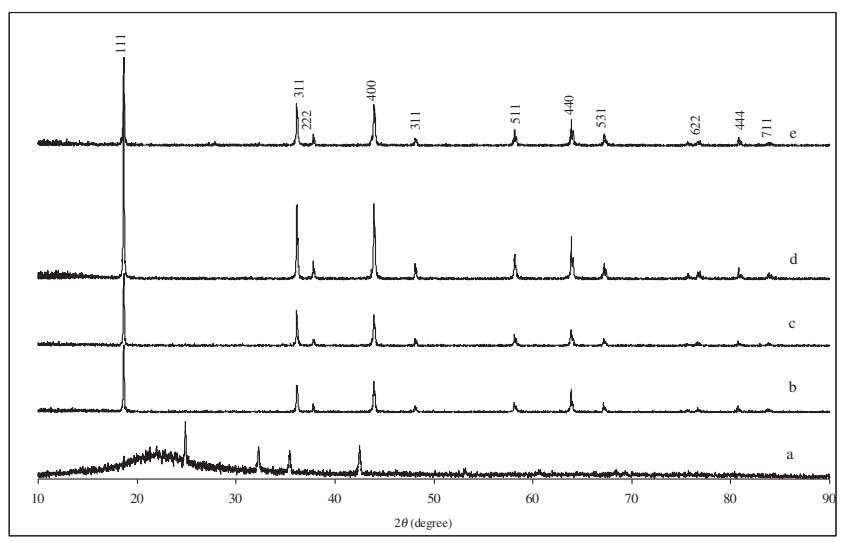

Figure 1. X-ray diffraction patterns of (a) LBS glass produced from calcination of the precursor powder of coating material, (b) bare $\mathrm{LiMn}_{2} \mathrm{O}_{4}$, (c) LBS-coated $\mathrm{LiMn}_{2} \mathrm{O}_{4}$, (d) $\mathrm{LiMn}_{1.9} \mathrm{Co}_{0.025} \mathrm{Cr}_{0.025} \mathrm{Ni}_{0.025} \mathrm{Fe}_{0.025} \mathrm{O}_{4}$ and (e) LBS-coated $\mathrm{LiMn}_{1.9} \mathrm{Co}_{0.025} \mathrm{Cr}_{0.025} \mathrm{Ni}_{0.025} \mathrm{Fe}_{0.025} \mathrm{O}_{4}$.
Charge-discharge tests were performed galvanostatically at a current rate of $1 \mathrm{C}$ with cut-off voltages of 3.5-4.5 V (vs. $\quad \mathrm{Li} / \mathrm{Li}^{+}$) at room temperature. All electrochemical experiments were performed using a multi-channel battery tester (PAR, Versa STAT MC Multichannel Potentiostat /Galvanostat). All processes of assembling and dismantling the cells were carried out in an argon-filled dry glove box.

\section{Results and discussion}

The composition of the synthesized samples was obtained through the ICP-MS analysis. As shown in table 1, it was found that the data were close to what we were expecting for the targeted formula. The structures of all these samples were characterized using XRD. The XRD patterns of the as-prepared samples, namely, undoped spinel $\left(\mathrm{LiMn}_{2} \mathrm{O}_{4}\right)$, LBS-coated $\mathrm{LiMn}_{2} \mathrm{O}_{4}$, doped spinel $\left(\mathrm{LiMn}_{1.9} \mathrm{Co}_{0.025} \mathrm{Cr}_{0.025} \mathrm{Ni}_{0.025} \mathrm{Fe}_{0.025} \mathrm{O}_{4}\right)$ and LBS-coated

Table 2. The cubic lattice parameters for $\mathrm{LiMn}_{2} \mathrm{O}_{4}$ and doped and LBS-coated samples.

\begin{tabular}{lc} 
Compounds & Lattice parameter $(\AA)$ \\
\hline Bare $\mathrm{LiMn}_{2} \mathrm{O}_{4}$ & $8.239(2)$ \\
$\mathrm{LBS}-$ coated $\mathrm{LiMn}_{2} \mathrm{O}_{4}$ & $8.234(2)$ \\
$\mathrm{LiMn}_{1.9} \mathrm{Co}_{0.025} \mathrm{Cr}_{0.025}$ & $8.237(2)$ \\
$\mathrm{Ni}_{0.025} \mathrm{Fe}_{0.025} \mathrm{O}_{4}$ & \\
$\mathrm{LBS}_{-}$coated $\mathrm{LiMn}_{1.9} \mathrm{Co}_{0.025} \mathrm{Cr}_{0.025^{-}}$ & $8.234(2)$ \\
$\mathrm{Ni}_{0.025} \mathrm{Fe}_{0.025} \mathrm{O}_{4}$ & \\
\hline
\end{tabular}
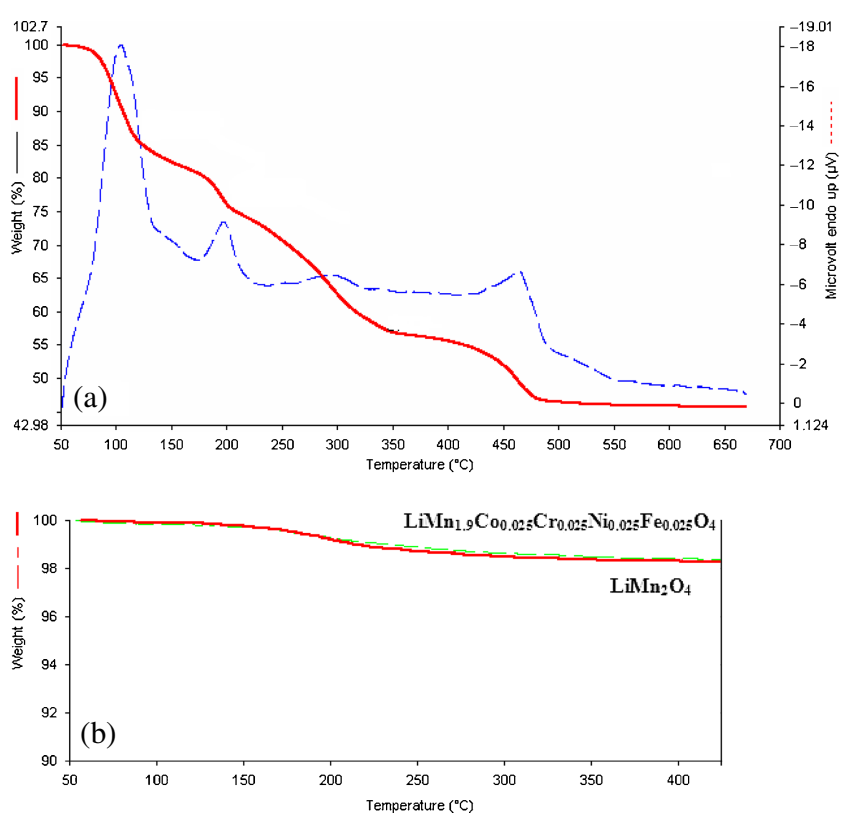

Figure 2. (a) Thermal gravimetric curve of LBS precursor powder as the coating medium obtained from evaporation of solution. ${ }^{39}$ (b) Thermal gravimetric curve of LBS precursor mixed cathode powders. 
$\mathrm{LiMn}_{1.9} \mathrm{Co}_{0.025} \mathrm{Cr}_{0.025} \mathrm{Ni}_{0.025} \mathrm{Fe}_{0.025} \mathrm{O}_{4}$ spinel are shown in figure $1 \mathrm{a}-\mathrm{d}$, respectively. It is obvious that the diffraction patterns of the four samples are characteristic of the spinel crystal structure, in which lithium ions occupy the $16 a$ positions of the tetrahedra, manganese ions $\left(\mathrm{Mn}^{3+}\right.$ and $\left.\mathrm{Mn}^{4+}\right)$ occupy the $16 d$ positions of the octahedra and oxygen ions occupy the $32 e$ positions, the vertices of the tetrahedra and octahedra. The same diffractions of spinel structure for the samples with and without doping indicate that the doped chromium, cobalt, iron and nickel has inserted the lattice of $16 d$ positions to replace manganese. The crystal lattice constants of all samples, as listed in table 2, clearly reveal that the values remain nearly unchanged with doping and coating. The ionic radius of six coordinate $\mathrm{Mn}^{4+}$ is $0.530 \AA$, but the ionic radius of six coordinate $\mathrm{Mn}^{3+}$ is $0.645 \AA$, while the ionic radii of sixth coordinate $\mathrm{Cr}^{3+}$, $\mathrm{Fe}^{3+}, \mathrm{Co}^{3+}$ and $\mathrm{Ni}^{2+}$ are $0.615,0.645,0.610$ and $0.690 \AA$, respectively. ${ }^{43}$ Because the avarage of the ionic radius of these cations is approximately equal to the $\mathrm{Mn}^{3+}$ cation, the calculated lattice parameter of the substituted spinel was not different from the undoped spinel $\mathrm{LiMn}_{2} \mathrm{O}_{4}$. In addition, almost no change in the lattice parameter for uncoated and coated samples existed suggesting that the LBS coating medium was not incorporated into the spinel structure but only presented on the surface of $\mathrm{LiMn}_{2} \mathrm{O}_{4}$, since $\mathrm{Li}^{+}, \mathrm{B}^{3+}$ and $\mathrm{Si}^{4+}$ introduction into the spinel structure leads to significant change in the lattice parameter. If $\mathrm{Li}^{+}, \mathrm{B}^{3+}$ and $\mathrm{Si}^{4+}$ ions were substituted for $\mathrm{Mn}^{3+}$ ions in the crystal lattice, the lattice parameter of the substituted spinel would be smaller than that of the undoped spinel $\mathrm{LiMn}_{2} \mathrm{O}_{4}$. This is due to the smaller size of $\mathrm{Li}^{+}(0.59 \AA)$, $\mathrm{B}^{3+}(0.27 \AA)$ and $\mathrm{Si}^{4+}(0.40 \AA)$ as compared with the larger $\mathrm{Mn}^{3+}(0.645 \AA) .{ }^{44}$

To determine the possible chemical composition of the coating layer, a thermal gravimetric examination of the precursor powder of the coating material, obtained from the evaporation of the LBS xerogel solution, was carried out and the results can be seen in figure 2 . The precursor obviously displays three important weight losses. The initial sharper endothermic peak occurred from 50 to $120^{\circ} \mathrm{C}$, attributed to the adsorbed water. The second, endothermic peak appeared at $150-300^{\circ} \mathrm{C}$. This peak was attributed to the thermal decomposition of nitrates. Finally, the third endothermic peak occurred between 350 and $500^{\circ} \mathrm{C}$. This last stage weight loss was due to thermal decomposition of organic species. Later, only a small amount of weight was lost, and the TG curve became smooth and flat, indicating that a stable complex had formed above $500^{\circ} \mathrm{C}$. Actual weight ratio of LBS
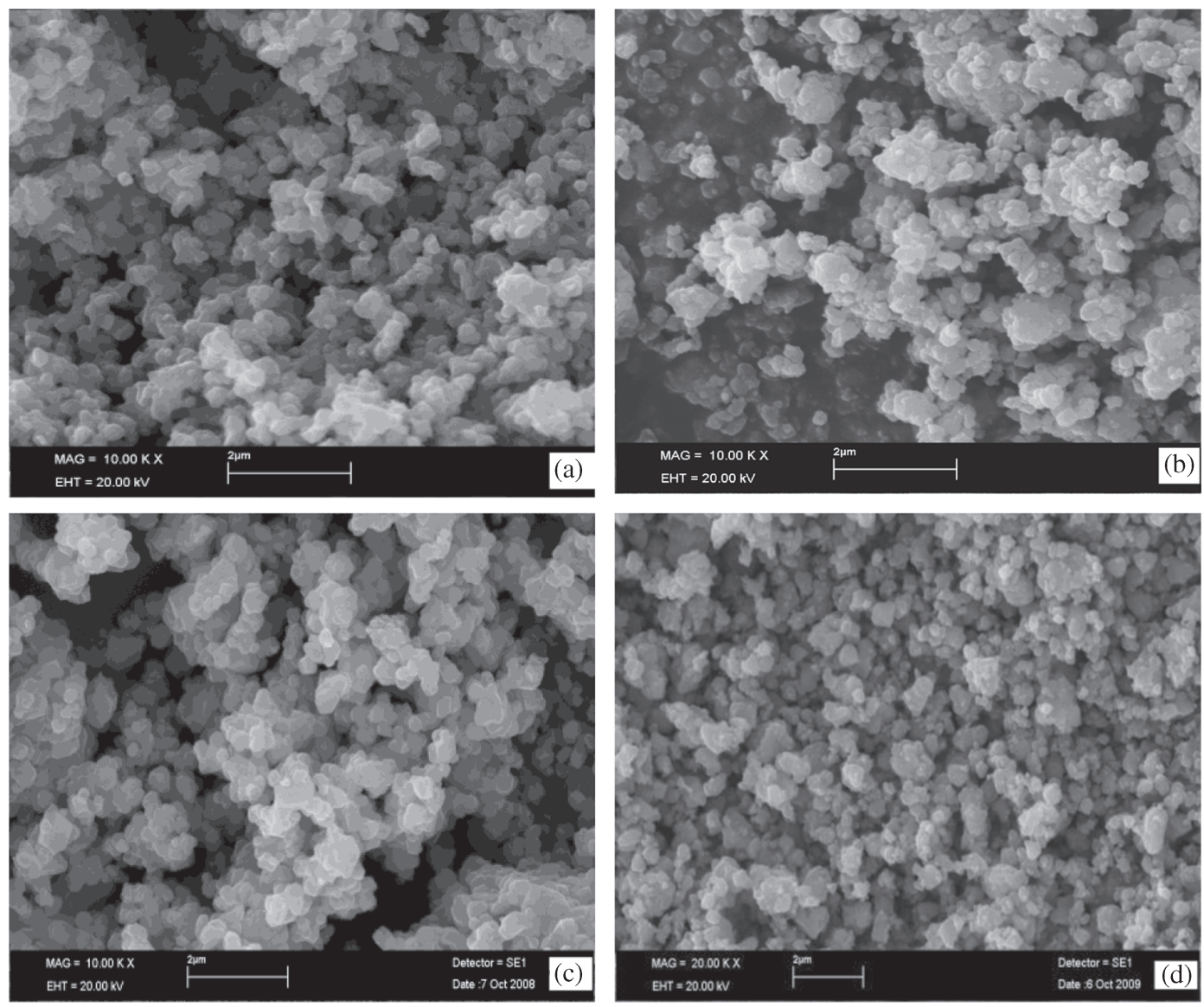

Figure 3. SEM images of (a) the uncoated $\mathrm{LiMn}_{2} \mathrm{O}_{4}$, (b) $\mathrm{LBS}$-coated $\mathrm{LiMn}_{2} \mathrm{O}_{4}$, (c) $\mathrm{LiMn}_{1.9} \mathrm{Co}_{0.025} \mathrm{Cr}_{0.025}$ $\mathrm{Ni}_{0.025} \mathrm{Fe}_{0.025} \mathrm{O}_{4}$ and (d) LBS-coated $\mathrm{LiMn}_{1.9} \mathrm{Co}_{0.025} \mathrm{Cr}_{0.025} \mathrm{Ni}_{0.025} \mathrm{Fe}_{0.025} \mathrm{O}_{4}$. 

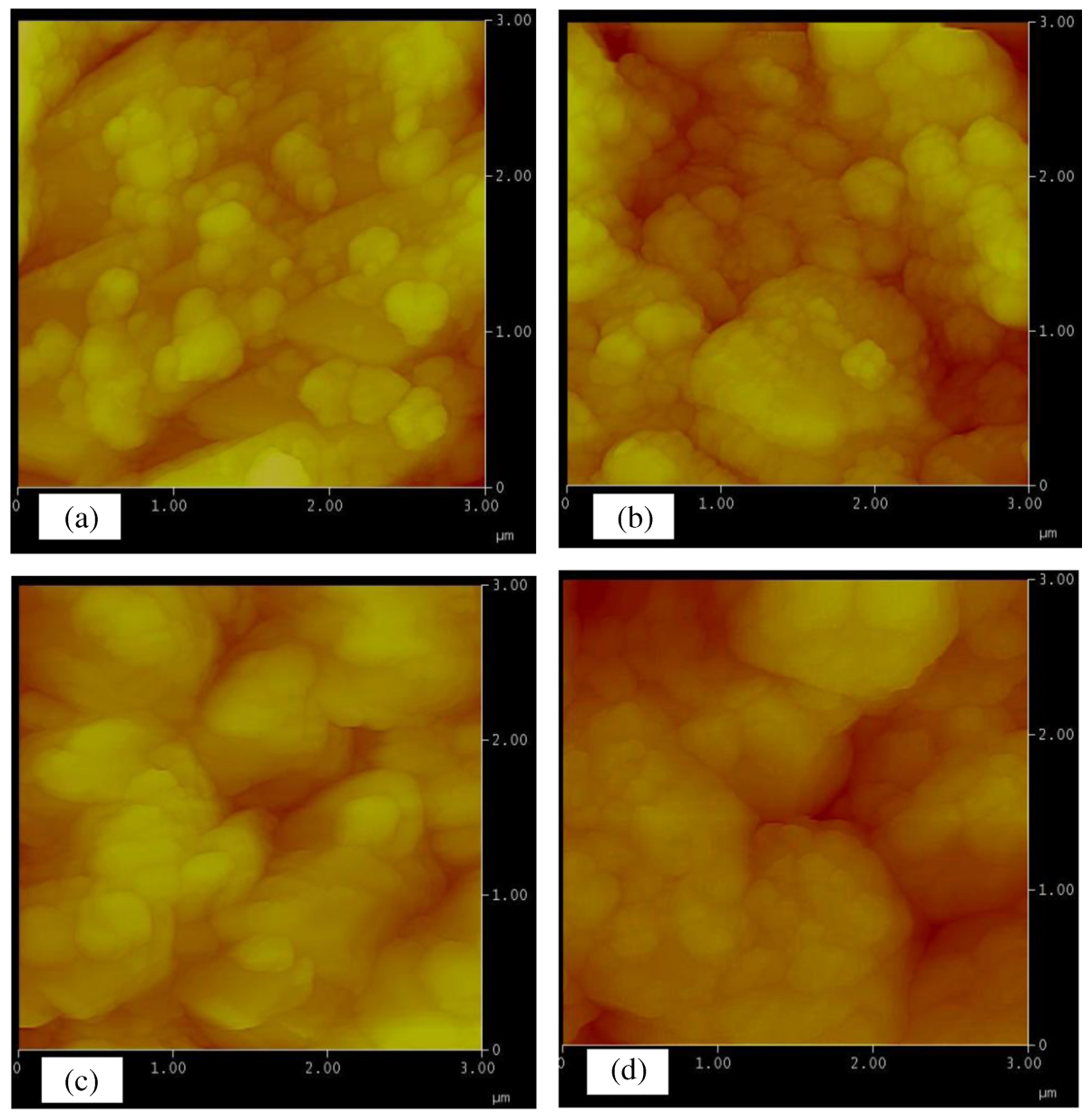

Figure 4. AFM images obtained in height mode of cathode surface in air at $3 \mu \mathrm{m}$ scan sizes. Samples were obtained from (a) uncoated $\mathrm{LiMn}_{2} \mathrm{O}_{4}$, (b) LBS-coated $\mathrm{LiMn}_{2} \mathrm{O}_{4}$, (c) $\mathrm{LiMn}_{1.9}$ $\mathrm{Co}_{0.025} \mathrm{Cr}_{0.025} \mathrm{Ni}_{0.025} \mathrm{Fe}_{0.025} \mathrm{O}_{4}$ and (d) LBS-coated $\mathrm{LiMn}_{1 .} \mathrm{Co}_{0.025} \mathrm{Cr}_{0.025} \mathrm{Ni}_{0.025} \mathrm{Fe}_{0.025} \mathrm{O}_{4}$ powder.

to pristine and doped $\mathrm{LiMn}_{2} \mathrm{O}_{4}$ samples were determined as a $1.9 \mathrm{wt} \%$. As can be seen from figure 1a calcination of the precursor powder at $425^{\circ} \mathrm{C}$ for $5 \mathrm{~h}$ exhibited a mixture of amorphous-semicrystalline LBS. Therefore, it is believed that the spinels shown in figure 1 are coated with LBS.

According to the morphological investigation of the uncoated $\mathrm{LiMn}_{2} \mathrm{O}_{4}$ and $\mathrm{LiMn}_{1.9} \mathrm{Co}_{0.025} \mathrm{Cr}_{0.025} \mathrm{Ni}_{0.025} \mathrm{Fe}_{0.025} \mathrm{O}_{4}$ the particles are smooth, as shown in figure $3 \mathrm{a}$ and c, but as shown in figure $3 \mathrm{~b}$ and $\mathrm{d}$, they become rough and aggregated after coating with LBS. Figure 4 shows the AFM images obtained in tapping mode of the cathode surface in air. Samples were obtained from uncoated and LBS-coated $\mathrm{LiMn}_{2} \mathrm{O}_{4}$, $\mathrm{LiMn}_{1.9} \mathrm{Co}_{0.025} \mathrm{Cr}_{0.025} \mathrm{Ni}_{0.025} \mathrm{Fe}_{0.025} \mathrm{O}_{4}$ particles. As shown in figure 5, the surface of the cathodes appears smooth and homogeneous. However the particles of LBS-coated cathodes were more aggregated than the uncoated ones.

Figure 5 shows the charge-discharge curves of $\mathrm{LiMn}_{2} \mathrm{O}_{4}$, $\mathrm{LiMn}_{1.9} \mathrm{Co}_{0.025} \mathrm{Cr}_{0.025} \mathrm{Ni}_{0.025} \mathrm{Fe}_{0.025} \mathrm{O}_{4}$, LBS-coated $\mathrm{LiMn}_{2} \mathrm{O}_{4}$ and LBS-coated $\mathrm{LiMn}_{1.9} \mathrm{Co}_{0.025} \mathrm{Cr}_{0.025} \mathrm{Ni}_{0.025} \mathrm{Fe}_{0.025} \mathrm{O}_{4}$ cathode materials at the $1 \mathrm{C}$ rate in the voltage range of 3.5$4.5 \mathrm{~V}$ at room temperature, respectively. It can be seen that they have similar charge-discharge profiles, exhibiting two pseudoplateaus at around 3.9 and $4.1 \mathrm{~V}$, which represents the typical electrochemical behavior of spinel $\mathrm{LiMn}_{2} \mathrm{O}_{4}{ }^{45} \mathrm{It}$ means that $\mathrm{Cr}, \mathrm{Co}, \mathrm{Fe}$ and Ni multi-doping did not change the intrinsic charge-discharge behaviour of $\mathrm{LiMn}_{2} \mathrm{O}_{4}$. The initial discharge capacities of the uncoated $\mathrm{LiMn}_{2} \mathrm{O}_{4}$ and doped samples are about 114.7 and $105.6 \mathrm{mAh} \mathrm{g}^{-1}$, respectively. The initial discharge capacities of doped $\mathrm{LiMn}_{2} \mathrm{O}_{4}$ decreases because of a decrease in the amount of extractable $\mathrm{Li}^{+}$ ion in the spinel. For $\mathrm{LiMn}_{1.9} \mathrm{Co}_{0.025} \mathrm{Cr}_{0.025} \mathrm{Ni}_{0.025} \mathrm{Fe}_{0.025} \mathrm{O}_{4}$, all doped cations replaced the place occupied originally by $\mathrm{Mn}^{3+}$ and the amount of $\mathrm{Mn}^{3+}$ in the spinel was reduced by the increasing amount of doped cations. Since $\mathrm{Co}^{3+}$, $\mathrm{Cr}^{3+}, \mathrm{Ni}^{2+}$ and $\mathrm{Fe}^{3+}$ ions cannot be oxidized in this potential range, the amount of removable $\mathrm{Li}^{+}$is determined by the amount of $\mathrm{Mn}^{3+} .{ }^{46}$ Briefly, the initial capacity can be estimated for the compound $\mathrm{LiM}_{x} \mathrm{Mn}_{2-\mathrm{x}} \mathrm{O}_{4}$ by the following formula: $C=148(1-(4-Z) X),{ }^{13}$ where $Z$ is the valance of the doped ion and $X$ the molar fraction of the dopant. Apparently, for the same doping level, $\mathrm{M}^{3+}$ shows much higher initial capacity. Therefore, in the following studies, 

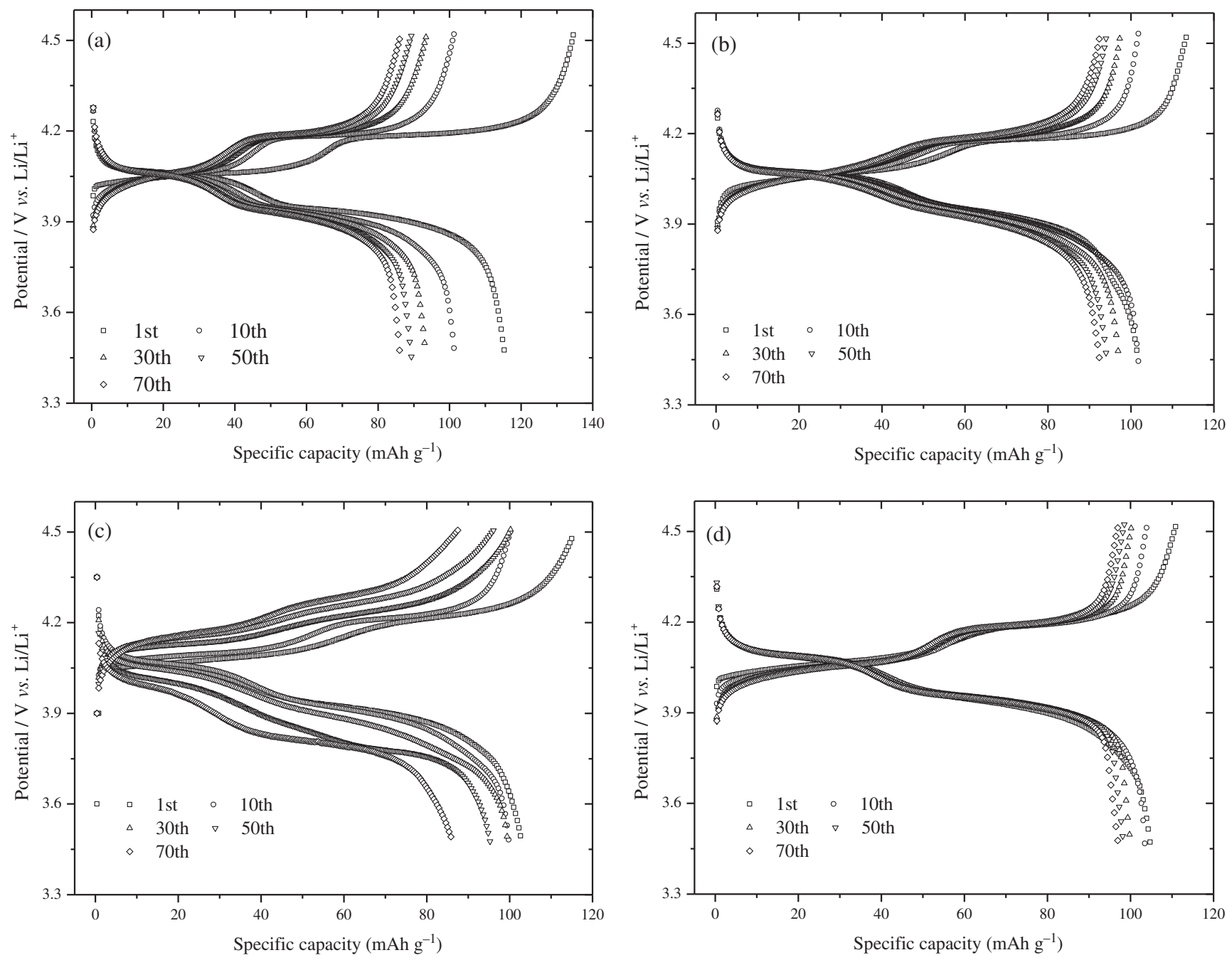

Figure 5. Continuous charge-discharge curves during 70 cycles: (a) the uncoated $\mathrm{LiMn}_{2} \mathrm{O}_{4}$ and (b) LBS-coated $\mathrm{LiMn}_{2} \mathrm{O}_{4}$, (c) $\mathrm{LiMn}_{1.9} \mathrm{Co}_{0.025} \mathrm{Cr}_{0.025} \mathrm{Ni}_{0.025} \mathrm{Fe}_{0.025} \mathrm{O}_{4}$ and (d) LBS-coated $\mathrm{LiMn}_{1.9} \mathrm{Co}_{0.025} \mathrm{Cr}_{0.025} \mathrm{Ni}_{0.025} \mathrm{Fe}_{0.025} \mathrm{O}_{4}$. The applied current density is $148 \mathrm{~mA} \mathrm{~g}^{-1}$ (1 C-rate) at room temperature. Li metal was used as the anode.

theoretical capacity of $\mathrm{LiMn}_{1.9} \mathrm{Co}_{0.025} \mathrm{Cr}_{0.025} \mathrm{Ni}_{0.025} \mathrm{Fe}_{0.025} \mathrm{O}_{4}$ cathode material was calculated as $129.5 \mathrm{mAh} \mathrm{g}^{-1}$.

It can be seen from figure $5 \mathrm{c}$ and $\mathrm{d}$ that the modification of $\mathrm{LiMn}_{2} \mathrm{O}_{4}$ and $\mathrm{LiMn}_{1.9} \mathrm{Co}_{0.025} \mathrm{Cr}_{0.025} \mathrm{Ni}_{0.025} \mathrm{Fe}_{0.025} \mathrm{O}_{4}$ with LBS does not change their charge and discharge characterization: two potential platforms for the lithium ion intercalation or de-intercalation into or from the spinel, for $\mathrm{Li}_{x} \mathrm{MnO}_{4}$ $0 \leq \mathrm{x} \leq 0.5$ and $0.5<x \leq 1$, respectively. It is found that there is a small loss in the charge or discharge capacity of the treated samples compared with the untreated samples, the discharge capacity is 102.3 and $105.6 \mathrm{mAh} \mathrm{g}^{-1}$, respectively. This can be explained by the fact that the LBS layer forms a barrier to the movement of $\mathrm{Li}$ ions, which impedes the extraction and insertion of $\mathrm{Li}$ ions from the spinel resulting in the low initial specific capacity of the cathode. ${ }^{47}$

$\mathrm{CV}$ measurements were carried out to further clarify the origin of multiple doping with $\mathrm{Cr}, \mathrm{Co}, \mathrm{Fe}$ and $\mathrm{Ni}$ and LBS coating did not change the intrinsic charge-discharge behaviour of coated $\mathrm{LiMn}_{2} \mathrm{O}_{4}$. Figure 6 shows the $\mathrm{CV}$ profiles of the pristine, multidoped and LBS-coated $\mathrm{LiMn}_{2} \mathrm{O}_{4}$ samples between 3.5 and $4.45 \mathrm{~V}$ with a scan rate of $0.1 \mathrm{mV} \mathrm{s}^{-1}$. It can be clearly observed that all products display two pairs of redox peaks between 3.8 and $4.3 \mathrm{~V}$, indicating $\mathrm{Li}^{+}$ are extracted and inserted into spinel $\mathrm{LiMn}_{2} \mathrm{O}_{4}$ by a twostep process. These results are strongly consistent with the first charge-discharge capacity curves, corresponding to two charge--discharge plateaus in the potential region of 3.9-4.1 V.

Figure 7 shows the result of discharge cycling at $1 \mathrm{C}$ rate between 3.5 and $4.5 \mathrm{~V}$ for $\mathrm{LiMn}_{2} \mathrm{O}_{4}, \mathrm{LiMn}_{1.9} \mathrm{Co}_{0.025}$ $\mathrm{Cr}_{0.025} \mathrm{Ni}_{0.025} \mathrm{Fe}_{0.025} \mathrm{O}_{4}$, LBS-coated $\mathrm{LiMn}_{2} \mathrm{O}_{4}$ and LBScoated $\mathrm{LiMn}_{1.9} \mathrm{Co}_{0.025} \mathrm{Cr}_{0.025} \mathrm{Ni}_{0.025} \mathrm{Fe}_{0.025} \mathrm{O}_{4}$ carried out at room temperature. The discharge capacities and percentage of capacity fading rate of all cathode materials as a function of cycle numbers are shown in table 3 . It should be noted that there is a significant difference in the discharge capacity vs. cycle numbers between these samples 

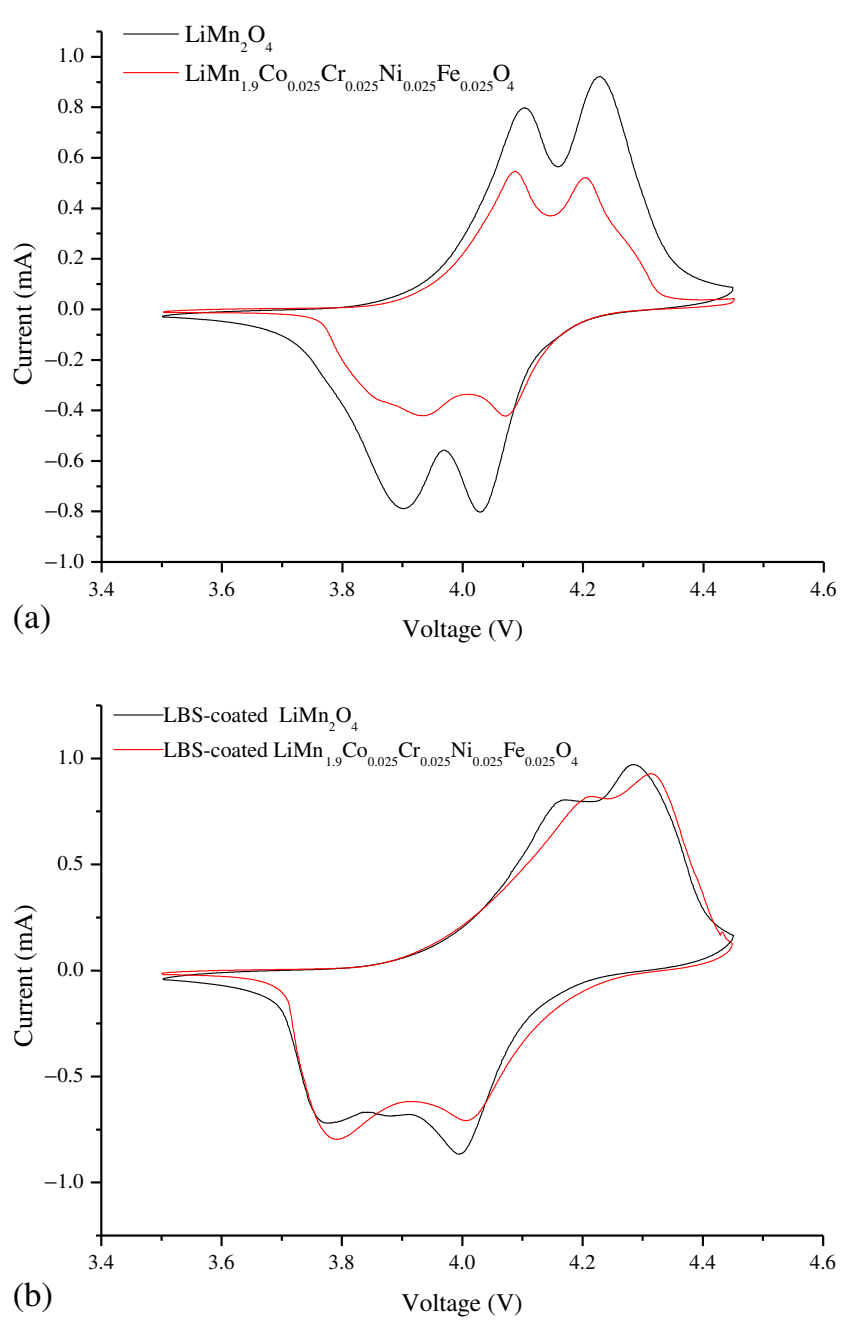

Figure 6. Cyclic voltammetry (CV) curves of (a) the pristine $\mathrm{LiMn}_{2} \mathrm{O}_{4}$ and $\mathrm{LiMn}_{1.9} \mathrm{Co}_{0.025} \mathrm{Cr}_{0.025} \mathrm{Ni}_{0.025} \mathrm{Fe}_{0.025} \mathrm{O}_{4}$ and (b) LBS-coated $\mathrm{LiMn}_{2} \mathrm{O}_{4}$ and $\mathrm{LiMn}_{1 .} \mathrm{Co}_{0.025} \mathrm{Cr}_{0.025} \mathrm{Ni}_{0.025} \mathrm{Fe}_{0.025} \mathrm{O}_{4}$ at a scan rate of $0.1 \mathrm{mV} \mathrm{s}^{-1}$.

(figure 7). The percentage of discharge capacity fading rate of the undoped spinel sample abruptly declines to $25.4 \%$ at the 70 th cycle at $1 \mathrm{C}$. For the doped sample, the discharge capacity fading ratio $(16.1 \%)$ is smaller than that of the undoped one over 70 cycles at the same C-rate. By contrast, the initial capacity of the undoped sample is higher than that of the doped sample which can be attributed to the small variations of manganase amount in the lattice frame. As expected, the doped spinel displays good cycle performance in terms of discharge capacity and cycle-life. The good cyclability is probably due to the substitution of some $\mathrm{Mn}-\mathrm{O}$ linkages in the spinel by $M-\mathrm{O}(M$ : $\mathrm{Co}, \mathrm{Cr}, \mathrm{Ni}$ and $\mathrm{Fe})$. The doped $\mathrm{Co}^{3+}, \mathrm{Cr}^{3+}, \mathrm{Ni}^{2+}$ and $\mathrm{Fe}^{3+}$ cations enhance the stability of the octahedral sites in the spinel skeleton structure. ${ }^{48}$ As for the LBS-coated cathode materials, in the same conditions, the initial discharge capacity of LBScoated $\mathrm{LiMn}_{2} \mathrm{O}_{4}$ declined from 102.3 to $91 \mathrm{mAh} \mathrm{g}^{-1}$ with a capacity fading ratio of $11 \%$ after 70 cycles. However,

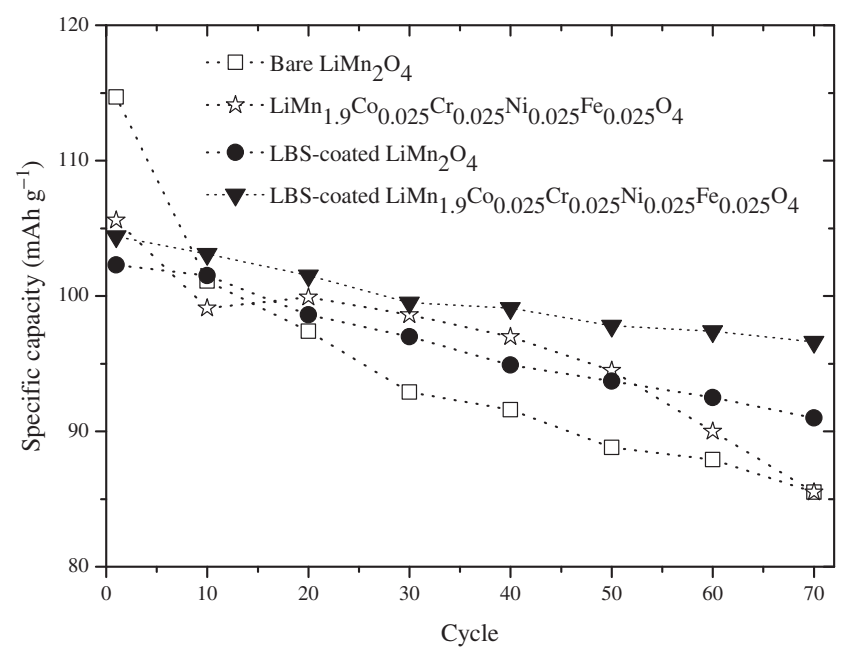

Figure 7. Cycling performance of all cathode materials at current level of $1 \mathrm{C}\left(148 \mathrm{mAh} \mathrm{g}^{-1}\right)$ in the voltage range of $3.5-4.5 \mathrm{~V}$ at room temperature.

LBS-coated $\mathrm{LiMn}_{1.9} \mathrm{Co}_{0.025} \mathrm{Cr}_{0.025} \mathrm{Ni}_{0.025} \mathrm{Fe}_{0.025} \mathrm{O}_{4}$ assures an initial discharge capacity of $105.6 \mathrm{mAh} \mathrm{g}^{-1}$ and remains at $96.6 \mathrm{mAh} \mathrm{g}^{-1}$ after 70 cycles, with a capacity fading ratio of $8.5 \%$. Electrochemical charge-discharge test results showed that the electrochemical cycling performance of $\mathrm{LiMn}_{2} \mathrm{O}_{4}$ enhanced with multication ( $\mathrm{Co}, \mathrm{Cr}, \mathrm{Ni}$ and $\mathrm{Fe}$ ) doping. However, the LBS-coated and multication-doped $\mathrm{LiMn}_{2} \mathrm{O}_{4}$ had the better cycling performance than the others. The LBS coating protected the spinel from electrolyte degredation. As we know, ${ }^{12-14,49,50}$ capacity loss caused by the dissolution of manganese accounted for $23 \%$ of overall capacity loss at room temperature. HF, generated during cycling when using $\mathrm{LiPF}_{6}$-based electrolyte, was responsible for the dissolution of manganese. In fact, preparation of $\mathrm{H}_{2} \mathrm{O}$-free electrolyte containing $\mathrm{LiPF}_{6}$ in organic solvent is difficult. A small amount of water (though the amount is less than 20 p.p.m) facilitates the decomposition of electrolytic salt, $\mathrm{LiPF}_{6}$. Thus, HF is formed as a by-product by the following reaction:

$$
\mathrm{LiPF}_{6}+\mathrm{H}_{2} \mathrm{O} \rightarrow \mathrm{LiF}+\mathrm{POF}_{3}+2 \mathrm{HF},
$$

HF contamination drastically increases the dissolution of manganese cations through the disproportionation of $\mathrm{Mn}^{3+}$, as reported by Jang et $a l^{49}$

$$
2 \mathrm{Mn}^{3+} \rightarrow \mathrm{Mn}^{2+}+\mathrm{Mn}^{4+} .
$$

Therefore the contact of the cathode with electrolyte would result in the dissolution of the cathode and do great harm to its performance. As we obtained in our previous study, ${ }^{39}$ the LBS coating prevented direct contact between the spinel and the electrolyte and therefore reduced the dissolution of manganese and the oxidation of electrolyte. These results indicate that Jahn-Teller distortion and the reaction of Mn dissolution in the cathode material were suppressed via the synergetic effect of multication doping and LBS coating. 
Table 3. Discharge capacity performance of bare $\mathrm{LiMn}_{2} \mathrm{O}_{4}$ and surface-treated $\mathrm{LiMn}_{2} \mathrm{O}_{4}$ cells ${ }^{\mathrm{a}}$.

\begin{tabular}{|c|c|c|c|c|c|c|}
\hline Cathode material & $1 \mathrm{st}$ & 10th & 30th & 50 th & 70th & $\begin{array}{l}\text { Capacity } \\
\text { loss }(\%)\end{array}$ \\
\hline $\mathrm{LiMn}_{2} \mathrm{O}_{4}$ & 114.7 & 101.1 & 92.9 & 88.8 & 85.5 & 25.4 \\
\hline $\mathrm{LiMn}_{1.9} \mathrm{Co}_{0.025} \mathrm{Cr}_{0.025} \mathrm{Ni}_{0.025} \mathrm{Fe}_{0.025} \mathrm{O}_{4}$ & 105.6 & 99.1 & 98.6 & 94.5 & 85.5 & 16.1 \\
\hline LBS-coated $\mathrm{LiMn}_{2} \mathrm{O}_{4}$ & 102.3 & 101.5 & 97.0 & 93.7 & 91.0 & 11.0 \\
\hline LBS-coated $\mathrm{LiMn}_{1.9} \mathrm{Co}_{0.025} \mathrm{Cr}_{0.025} \mathrm{Ni}_{0.025} \mathrm{Fe}_{0.025} \mathrm{O}_{4}$ & 105.6 & 103.1 & 99.5 & 97.8 & 96.6 & 8.50 \\
\hline
\end{tabular}

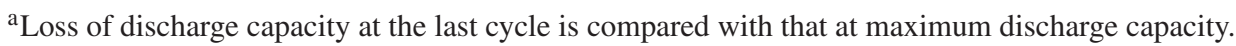

\section{Conclusions}

New Co-, Cr-, Ni- and Fe-substituted compounds were synthesized by using the glycine-nitrate combustion method and coated with LBS via the solution method. The effects of doping and coating on the electochemical properties of $\mathrm{LiMn}_{2} \mathrm{O}_{4}$ were studied using electrochemical chargedischarge tests and XRD, SEM, AFM and ICP-MS methods. The XRD pattern for Co-, $\mathrm{Cr}-$, Ni- and Fe-doped and LBS-coated spinel did not show any change in the $2 \theta$ value of the peaks and no impurities were detected. The similar lattice parameters of the coated and uncoated samples indicated that the LBS layer only coated the surface rather than diffusing into the crystal. Compared with the uncoated $\mathrm{LiMn}_{2} \mathrm{O}_{4}$ and $\mathrm{LiMn}_{1.9} \mathrm{Co}_{0.025} \mathrm{Cr}_{0.025} \mathrm{Ni}_{0.025} \mathrm{Fe}_{0.025} \mathrm{O}_{4}$, on line the LBS-coated $\mathrm{LiMn}_{1.9} \mathrm{Co}_{0.025} \mathrm{Cr}_{0.025} \mathrm{Ni}_{0.025} \mathrm{Fe}_{0.025} \mathrm{O}_{4}$ sample exhibited an improved cycling stability at room temperature compared with the undoped and doped one. The capacity losses in the first 70 cycles between 3.5 and $4.5 \mathrm{~V}$ decrease significantly from $25.4 \%, 16.1 \%$ and $11 \%$ for uncoated $\mathrm{LiMn}_{2} \mathrm{O}_{4}, \mathrm{LiMn}_{1.9} \mathrm{Co}_{0.025} \mathrm{Cr}_{0.025} \mathrm{Ni}_{0.025} \mathrm{Fe}_{0.025} \mathrm{O}_{4}$ and LBScoated $\mathrm{LiMn}_{2} \mathrm{O}_{4}$, respectively. The LBS-coated $\mathrm{LiMn}_{1.9}$ $\mathrm{Co}_{0.025} \mathrm{Cr}_{0.025} \mathrm{Ni}_{0.025} \mathrm{Fe}_{0.025} \mathrm{O}_{4}$ showed $8.5 \%$ capacity loss of the initial discharge capacity. The results suggested that the as-prepared LBS-coated $\mathrm{LiMn}_{1.9} \mathrm{Co}_{0.025} \mathrm{Cr}_{0.025} \mathrm{Ni}_{0.025} \mathrm{Fe}_{0.025}$ could be a promising cathode material for lithium ion batteries.

\section{Acknowledgements}

This study was financially supported by the Erciyes University Research Fund project number FBA-08-439.

\section{References}

1. Scrosati B 1995 Nature 373557

2. Chung S-Y, Bloking J T and Chiang Y-M 2002 Nat. Mater. 1123

3. Whittingham M S 2004 Chem. Rev. 104271

4. Kang K, Meng Y S, Berger J et al 2006 Science 311977

5. Thackeray M M, Johnson P J, Depicciotto L A et al 1984 Electrochem. Mater. Res. Bull. 19179

6. Thackeray M M and Dekock A J 1988 J. Solid State Chem. 74 $414 \mathrm{R}$
7. Jayalakshmi M, Mohan Rao M and Scholz F 2003 Langmuir 198403

8. Cabana J, Valdés-Solís T, Palacín M R et al 2007 J. Power Sources 166492

9. Luo J-Y, Wang Y-G, Xiong H-M et al 2007 Chem. Mater. 19 4791

10. Pasquier A D, Blyr A, Courjal P et al 1999 J. Electrochem. Soc. 146428

11. Cho J and Thackeray M M 1999 J. Electrochem. Soc. 1463577

12. Xia Y, Zhou Y and Yoshio M 1997a J. Electrochem. Soc. 144 2593

13. Xia Y, Okada M, Nagano M et al 1997b The Electrochemical Society proceeding series (Pennington) p. 494

14. Xia Y, Zhou Y and Yoshio M 1997c J. Electrochem. Soc. 144 2593

15. Xia Y, Sakai T, Fujieda T et al 2001 J. Electrochem. Soc. 148 A723

16. Amatucci G G, Pereira N, Zheng T et al 2001 J. Electrochem. Soc. 148 A 171

17. Larcher D, Gerand B and Tarascon J M 1998 J. Solid State Electrochem. 2137

18. Shin Y and Manthiram A 2003 Chem. Mater. 152954

19. Kannan A M and Manthiram A 2002 Electrochem. Solid-State Lett. 5 A 167

20. He X, Li J, Cai Y et al 2005 J. Power Sources 150216

21. Sun Y-K, Hong K-J, Prakash J et al 2002 Electrochem. Commun. 4344

22. Park S C, Han Y-S, Kang Y-S et al 2001 J. Electrochem. Soc. 148680

23. Park S B, Lee S M, Shin H C et al 2007 J. Power Sources 166 219

24. Liu D, Liu X and He Z 2007a Mater. Chem. Phys. 105362

25. Liu D, He Z and Liu X 2007b Mater. Lett. 614703

26. Ha H-O, Yun N J and Kim K 2007 Electrochim. Acta 523236

27. Thirunakaran R, Ravikumar R and Vanitha S 2011 Electrochim. Acta $\mathbf{5 8} 348$

28. Bittihn R, Herr R and Hoge D 2007 J. Power Sources 43/44 223

29. Guohua L, Ikuta H, Uchida T et al 1996 J. Electrochem. Soc. 143178

30. Banov B, Todorov Y, Trifonova A et al 1997 J. Power Sources 68578

31. Schmutz G G, Amatucci C N, Mlyr A et al 1997 J. Power Sources 6911

32. Noguchi T, Yamazaki I, Numata T et al 2007 J. Power Sources 174359 
33. Chan W, Duh J G and Sheu H S 2006 J. Electrochem. Soc. 153 A1533

34. Sahan H, Göktepe H, Patat Ş et al 2010 Solid State Ionics 181 1437

35. Lee S-W, Kim K-S, Moon H-S et al 2004 J. Power Sources 126 150

36. Cho J, Kim T-J, Kim Y-J et al 2001 Chem. Commun. 121074

37. Tu J, Zhao X-B, Cao G-S et al 2006 Electrochim. Acta 51 6456

38. Han J-M, Myung S-T and Sun Y-K 2006 J. Electrochem. Soc. 153 A 1290

39. Sahan H, Göktepe H, Patat Ş et al 2011 J. Alloys Compd. 509 4235

40. Zhang Y, Shin C H, Dong J et al 2004 Solid State Ionics 17125

41. Muralidharan P and Venkateswarlu M 2004 N. Mater. Chem. Phys. 88138
42. Armarego W-L-F and Perrin D-D 2002 Purification of laboratory chemicals (Oxford: Butterworth Heinemann) 4th ed

43. Shannon R-D 1976 Acta Crystallogr. A32 751

44. Green D-W and Perry R-H 2008 Perry's Chemical engineers' handbook (New York: McGraw-Hill) 8th ed

45. Kim D-K, Muralidharan P, Lee H-W et al 2008 Nano Lett. 8 3948

46. Wohlfahrt-Mehrens M, Butz A, Oesten R et al 1997 J. Power Sources $\mathbf{6 8} 582$

47. Xia Y and Yoshio M 1996 J. Electrochem. Soc. 143825

48. Oikawa K, Kamiyama T, Izumi F et al 1999 J. Solid State Chem. 146322

49. Jang D-H, Shin Y-J and Oh S-M 1996 J. Electrochem. Soc. 143 2204

50. Myung S-T, Izumi K, Komaba S et al 2005 Chem. Mater. 17 3695 